\title{
Investigating Consumer Preference for Organic, Local, or Sustainable Plants
}

\author{
Chengyan Yue ${ }^{1,7}$ \\ Department of Applied Economics and Department of Horticultural Science, \\ University of Minnesota, 1970 Folwell Avenue, St. Paul, MN 55108
}

Jennifer H. Dennis ${ }^{2}$

Department of Horticulture and Landscape Architecture, Purdue University, 625 Agriculture Mall Drive, West Lafayette, IN 47907

Bridget K. Behe
Department of Horticulture, Michigan State University, 238 Plant and Soil
Sciences Building, East Lansing, MI 48824-1325

Charles R. Hall ${ }^{4}$

Department of Horticultural Sciences, Texas A\&M University, 202 Hort/ Forest Science Building, 2133 TAMU, College Station, TX 77843-2133

\author{
Benjamin L. Campbell ${ }^{5}$ \\ Vineland Research and Innovation Centre, 4890 Victoria Avenue North, P.O. \\ Box 4000, Vineland Station, Ontario, Canada LOR 2EO
}

\author{
Roberto G. Lopez 6 \\ Department of Horticulture and Landscape Architecture, Purdue University, \\ 625 Agriculture Mall Drive, West Lafayette, IN 47907 \\ Additional index words. biodegradable pots, compost pots, ecofriendly, energy-efficient, \\ recycled pots
}

\begin{abstract}
Organically and locally grown food products have become increasingly popular in recent years. However, unlike food products, consumers purchase most outdoor plants for their aesthetic value rather than their nutritional value. Many of the health concerns related to food products might not be applicable to ornamental plants, so the demand for organic non-food plants is unknown. Using a survey with 834 participants from four states, we investigated consumer preference for ornamentals, vegetable transplants, and herbs grown: 1) organically, locally, and sustainably; 2) in energy-efficient greenhouses; and 3 ) in biodegradable, compostable, and recyclable containers. Our study found that consumers are not enthusiastic about plants or their fertilizers being "organic." However, consumers are very interested in plants being produced locally, similar to the public's everincreasing interest in local food products. Consumers are also interested in purchasing plants in containers that are more sustainable. Among the different types of containers, biodegradable and compostable pots are more desirable than recycled pots.
\end{abstract}

In 2009, bedding plants accounted for $\$ 1.81$ billion in sales based on data collected from 15 states by the U.S. Department of Agriculture (USDA) National Agriculture Statistics Service

Received for publication 24 Nov. 2010. Accepted for publication 16 Jan. 2011.

We gratefully acknowledge funding from the American Floral Endowment (AFE), the Horticultural Research Institute (HRI), and the USDA FederalState Marketing Improvement Program (FSMIP) that was instrumental in conducting this research effort.

${ }^{1}$ Assistant Professor and Bachman Endowed Chair in Horticultural Marketing.

${ }^{2}$ Associate Professor.

${ }^{3}$ Professor.

${ }^{4}$ Professor and Ellison Chair in International Floriculture.

${ }^{5}$ Research Scientist.

${ }^{6}$ Assistant Professor and Floriculture Extension Specialist.

${ }^{7}$ To whom reprint requests should be addressed; e-mail yuechy@umn.edu. ucts or the entire output of that business. Previous studies have shown that consumer demand for environmentally conscious products and business practices is rapidly rising (Yue et al., 2010a,b). Consumers are also increasingly concerned about the origin of products they buy and how they were produced; at least some consumers may be more willing to pay a premium price or shop exclusively at one business over another if they know that products are grown locally or in a sustainable manner (Yue et al., 2009).

Previous studies have also shown that consumers are interested in ecofriendly products and the use of ecolabels has grown rapidly worldwide (Basu et al., 2004). Other studies on ecolabeling have shown that consumers are often willing to pay more for ecofriendly products: Blend and Van Ravenswaay (1999), Thompson and Kidwell (1998), and Yue et al. (2009) for apples; Wessels et al. (1999) for seafood; Veisten (2007) for wood furniture; and Nimon and Beghin (1999) for apparel. Organically grown food products have become increasingly popular in recent years. Global sales of organic food products have increased at a rate of more than $\$ 5$ billion annually (Willer et al., 2008). There are many factors that influence consumers to buy organic produce, including: 1) their perceptions regarding healthfulness, environmental friendliness, taste, freshness, quality; and 2) their desire to avoid genetically modified foods (Demeritt, 2002; Schifferstein and Oude Ophuis, 1998; Yue et al., 2009). Locally grown food products have appealed to an increasing number of consumers in the past several years. Previous studies that focused on choices at farmers' markets showed that consumers expect higher quality (for example, freshness and taste) and lower prices (Brown, 2002, 2003). Besides attributes such as freshness and being safe to eat, one of the most important motivations underlying their choice of locally grown food is that they feel they are supporting the local economy (Yue and Tong, 2009).

There is a belief that the demand for organic and sustainable flower products is increasing in the United States as a result of an emerging market segment focused on health and fitness, the environment, personal development, sustainable living, and social justice (Stewart, 2007). Researchers recently investigated consumer preferences for selected sustainable ornamental products and practices (Hall et al., 2010; Yue et al., 2010b) and found that one important attribute involved in the consumer's decision to purchase a plant was the type of container in which it was grown. However, no formal studies have systematically investigated the level of consumer interest in plants that are produced in a sustainable manner.

Often product characteristics are also considered using the dichotomy between intrinsic and extrinsic product attributes (Olson and Jacoby, 1972). Intrinsic attributes are attributes of the physical product itself (e.g., the color of flowers). Extrinsic attributes include those not directly associated with the physical product such as price and product origin (e.g., locally grown plants). Product quality can be 
defined in terms of the moment at which the consumer receives information about the characteristics of the products while shopping or consuming it (Becker, 2000). There are three categories of quality attributes: search characteristics, experience characteristics, and credence characteristics. Search characteristics are those intrinsic and extrinsic quality attributes that can be ascertained before the purchase; for example, the color and height of an ornamental plant. In contrast, experience characteristics are the intrinsic attributes that can only be established by experiencing the product; for example, the taste of herbs. Credence characteristics cannot be validated (or can be validated only at very high cost) by consumers either before or even after the purchase; for example, the health benefits from consuming herbs. Unlike food products, consumers purchase most plants for their aesthetic value (search characteristics that can be validated at the moment of purchase) instead of their nutritional value or eating quality (experience characteristics or even credence characteristics that cannot be validated at the moment of purchase). Many of the health concerns related to food products at the moment of purchase might not be applicable to plants. Therefore, earlier findings about consumer preferences for sustainable food products might not apply to plants, especially ornamental plants, yet a desire to support the local economy may extend to non-edible plants.

In this study, we tested two hypotheses: 1) consumers are more interested in ornamentals, vegetable transplants, and herbs grown in sustainable ways than conventionally grown plants; and 2) consumers have different levels of interest in local plants, organic plants, and plants grown with different sustainable production methods. We included organic and local attributes, because most consumer studies have in the past as well as attributes related to plants grown in a sustainable manner (sustainable plants).

\section{Materials and Methods}

An Internet survey was conducted to investigate consumers' interest in sustainably grown plants compared with conventionally grown plants. The survey was administered through the Internet accessing a sample of 300 consumers each from Indiana, Michigan, Minnesota, and Texas, whose average demographic characteristics were representative of the population at large in those states. The Internet survey was developed by the researchers and approved by the university committees involved with research on human subjects. The survey was then implemented by Knowledge Networks during July 2009. This firm (http://www.knowledgenetworks. com/index $5 . \mathrm{html}$ ) conducts survey research for economic, social, and political clients that include Stanford and Harvard universities and CBS News. Advantages of web-based surveys, according to McCullough (1998), are they are potentially faster to conduct than telephone or face-to-face interviews and generate more accurate information with less human error.
The data were collected during July 2009 using Knowledge Network's web-enabled KnowledgePanel®. This is a probability-based consumer panel designed to be representative of the U.S. population. The survey was administered through the Internet accessing a sample of 300 KnowledgePanel consumers from Indiana, Michigan, Minnesota, and Texas. Knowledge Networks provides Internet access to potential respondents without it, thereby eliminating that potential bias. Before the formal Internet survey was sent to a larger sample of participants, Knowledge Networks conducted an online pretest of the questionnaire with a smaller sample to ensure the questions were easily understood. To eliminate possible non-response bias, Knowledge Networks provided weights that were used to correct for such bias in our statistical analysis. To eliminate respondents who do not purchase outdoor plants, we asked potential respondents if they had purchased any plants for any type of outdoor use during the last year (since July 2008). If the respondent did not purchase any plants, then the survey ended and the respondent did not proceed to subsequent questions. An answer of "yes" gave the respondent access to the remainder of the survey. The survey was comprised of the following questions: how much participants have spent on plants in the past year; types (annual, perennial, herbs, and vegetable; shrubs and woody plants, trees, indoor plants, etc.) and amounts of plants purchased in the past year; participants' perception of "sustainability"; what percent of their total household budget was spent on organic food; and how interested they would be in purchasing selected plant types, including conventional plants, organic plants, sustainable plants, locally produced plants, plants grown with organic fertilizers, plants grown in energy-efficient greenhouses, plants grown in biodegradable pots, plants grown in compostable pots, and plants grown in recyclable pots. We used a 7-point Likert scale to elicit consumer interest in these different types of plants with 1 conveying "low interest" and 7 meaning "high interest."

A total of 1113 people participated in the survey with 834 participants completing the survey. The remainder of the respondents did not finish the survey because they did not purchase any ornamental plants in the past year. Because the dependent variables were categorical and ordinal (seven levels of interest in different plants), we used a mixed order probit model to estimate the probability of a consumer's interest in different plants (Yue and Behe, 2008).

Consumers' satisfaction with and interest in the alternative plant types is correlated with certain measurable factors, including the consumers' demographic characteristics, the amount spent on plant-related products and organic food products, and the types of plants they purchased. Demographic characteristics of consumers included age, gender, education, household size, marital status, income, Metropolitan Statistical Area (MSA), etc. We used the mixed order probit model to analyze consumers' opinion or attitudinal data. When the survey asked the respondents' opinion, the intensity of their feelings was dependent on various factors, some measurable and some unobservable. We also included preference questions related to more detailed sustainable production methods such as plants grown using organic fertilizers, plants grown in energyefficient greenhouses, and plants grown in different types of pots. Findings about the consumers' interest in more sustainable plant production methods can provide clear guidance to plant producers on what types of sustainable practices to adopt to remain profitable and competitive in the marketplace.

In many situations, the respondents were given only a set number of possible answers, say seven, to the question of $y$. Consumers choose the cell that most closely represents the intensity of response to the question. The consumers' choice of the seven categories is dependent on an underlying satisfaction function from certain products' attributes. Suppose $U_{i j}$ is the satisfaction that consumer $i$ derives from product $j$ 's certain attribute and $U_{i j}$ can be expressed as follows:

$$
\begin{aligned}
U_{i j} & =X_{i} \beta_{j}+\gamma_{i}+\varepsilon_{i j}, i=1,2, \ldots, n \\
j & =1,2, \ldots, J
\end{aligned}
$$

where $X_{i}$ is the design matrix, which includes product quality attributes; $\beta_{j}$ is the coefficient associated with $X_{i} ; \gamma_{i}$ is the random individual effect, which is assumed to follow normal distribution with mean zero and SD $\sigma_{\gamma}$; the random individual effect is used to capture the correlation between the choices on multiple products made by the same individual; and $\varepsilon_{i j}$ is the residual error term that is not captured by design matrix $X_{i}$, which is assumed to follow normal distribution with mean zero and SD $\sigma_{\varepsilon}$. There are $n$ consumers and $J$ products. $U_{i j}$ cannot be observed. What we observe is the $i$ th consumer's choice, which is denoted as $Y_{i j}$.

$$
\begin{array}{clll}
y_{i j}=0 & \text { if } & U_{i j} \leq u_{0 j} \\
y_{i j}=1 & \text { if } & u_{0 j}<U_{i j} \leq u_{1 j} \\
y_{i j}=2 & \text { if } & u_{1 j}<U_{i j} \leq u_{2 j} \\
\vdots & & \\
y_{i j}=K & \text { if } & u_{k-1, j} \leq U_{i j}
\end{array}
$$

The structure of Eq. (2) is a form of censoring for $i=1, \cdots, n ; j=1 \cdots J$. The $u$ 's are unknown "cutoff points" parameters, which can be estimated. When analyzing how sociodemographic background affected consumer interest in each plant type, we used the ordered probit model instead of the mixed order probit model without $\gamma_{i}$ in Eq. (1). This is because we analyzed each type of plant separately and there was no individual effect to capture.

\section{Results and Discussion}

Table 1 shows the summary statistics of Internet survey respondents' background information. The average age of the participants was 47 years; the average education level was some college; $52 \%$ of participants were female; $53 \%$ of participants were married; $25 \%$ 
of them had children younger than 12 years old; $84 \%$ had a detached family house; participants' average income was between $\$ 40,000$ and $\$ 50,000$; on average, there were three people per household; and less than $25 \%$ of their household food budget was spent on organic food. The average annual dollar amount participants spent on gardening-related products was $\$ 51$ to $\$ 100 ; 57 \%$ of participants had bought annual plants in the past year; $47 \%$ had purchased perennial plants in the past year; $45 \%$ had purchased herbs or vegetable plants; $21 \%$ had purchased shrubs; $13 \%$ had purchased trees; $27 \%$ had purchased indoor plants; $81 \%$ participants were from urban area; and participants were evenly distributed across the four states (Indiana, Michigan, Minnesota, and Texas).

Table 1. Summary statistics of background information associated with participants in an online survey regarding consumer attitudes and preferences for locally grown, organically grown, or sustainably grown ornamental plants.

\begin{tabular}{|c|c|c|c|}
\hline Variable & Description of variables & Mean & SD \\
\hline$\overline{\text { Age }}$ & Age of participants, continuous variable & 47.22 & 16.56 \\
\hline Education & $\begin{array}{l}\text { Participants' education level: } \\
1=\text { less than high school } \\
2=\text { high school } \\
3=\text { some college } \\
4=\text { Bachelor's degree or higher }\end{array}$ & 2.70 & 0.92 \\
\hline Gender & $\begin{array}{l}\text { Participants' gender: } \\
1=\text { female }, 0=\text { male }\end{array}$ & 0.52 & 0.50 \\
\hline Marriage & $\begin{array}{l}\text { Participants' marital status: } \\
1=\text { married, } 0=\text { otherwise }\end{array}$ & 0.53 & 0.50 \\
\hline Children & $\begin{array}{l}\text { If participants have children younger than } \\
12 \text { years old: } \\
1=\text { yes, } 0=\text { no }\end{array}$ & 0.25 & 0.43 \\
\hline House type & $\begin{array}{l}\text { Participants' house type: } \\
1=\text { one family house detached from any other } \\
\text { house, } 0=\text { otherwise }\end{array}$ & 0.84 & 0.37 \\
\hline Income & $\begin{array}{l}\text { Participants' income: } \\
\begin{array}{l}1=\text { less than } \$ 5,000,2=\$ 5,000-\$ 7,499, \\
3=\$ 7,500-\$ 9,999,4=\$ 10,000-\$ 12,499, \\
5=\$ 12,500-\$ 14,999,6=\$ 15,000-\$ 19,999, \\
7=\$ 20,000-\$ 24,999,8=\$ 25,000-\$ 29,999, \\
9=\$ 30,000-\$ 34,999,10=\$ 35,000-39,999, \\
11=\$ 40,000-\$ 49,999,12=\$ 50,000-\$ 59,999, \\
13=\$ 60,000-\$ 74,999,14=\$ 75,000-\$ 84,999, \\
15=\$ 85,000-\$ 99,999,16=\$ 100,000-\$ 124,999, \\
17=\$ 12,500-\$ 149,999,18=\$ 150,000-174,999, \\
19=\$ 175,000 \text { or more }\end{array}\end{array}$ & 11.02 & 4.09 \\
\hline Household size & Participants' household size, continuous variable & 2.69 & 1.39 \\
\hline Organic food & $\begin{array}{l}\text { Percentage of participants' food budget used to } \\
\text { purchase organic food product: } \\
\begin{array}{l}1=0 \\
2=1 \text { ess than } 25 \% \\
3=25 \% \text { to } 49 \% \\
4=50 \% \text { to } 74 \% \\
5=75 \% \text { or greater }\end{array}\end{array}$ & 1.34 & 1.01 \\
\hline Total spent & 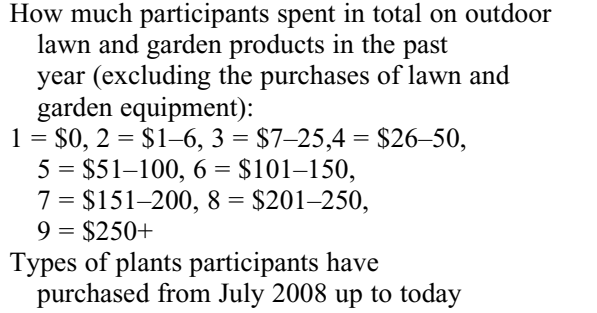 & 4.83 & 2.63 \\
\hline Annual & $\begin{array}{l}\text { Flowering annual plants for } \\
\text { outdoor use on porch, deck, } \\
\text { patio, or in landscape }\end{array}$ & 0.57 & 0.49 \\
\hline Perennial & Flowering perennial plants for outdoor use & 0.47 & 0.50 \\
\hline Herb vegetable & Herbs or vegetable plants & 0.45 & 0.50 \\
\hline Shrub & $\begin{array}{l}\text { Flowering shrubs with a woody stem for outdoor } \\
\text { landscape }\end{array}$ & 0.21 & 0.40 \\
\hline Tree & Trees (either evergreen or deciduous) & 0.13 & 0.34 \\
\hline Indoor plant & $\begin{array}{l}\text { Indoor flowering plants (for example, } \\
\text { poinsettia or chrysanthemum) }\end{array}$ & 0.27 & 0.44 \\
\hline MSA & $\begin{array}{l}\text { MSA status, } 1=\text { urban or suburbs, } \\
0=\text { otherwise }\end{array}$ & 0.81 & 0.39 \\
\hline StateIN & Participants are from Indiana & 0.24 & 0.43 \\
\hline StateMI & Participants are from Michigan & 0.27 & 0.44 \\
\hline StateMN & Participants are from Minnesota & 0.24 & 0.43 \\
\hline StateTX & Participants are from Texas & 0.24 & 0.43 \\
\hline
\end{tabular}

MSA $=$ Metropolitan Statistical Area.

Table 2 shows the participants' average interest in several plant categories. From the mean values, we can see that participants show the highest interest in plants grown in biodegradable pots and locally produced plants followed by plants grown in compostable pots and recyclable pots. Participants were least interested in organic plants and plants grown using organic fertilizers. Participants exhibited a medium level of interest in sustainable plants and plants grown in energy-efficient greenhouses (Table 2).

To test if participants' interests in different types of plants were significantly different from each other, we ran the mixed order probit model using interest level (1 to 7) as the dependent variable and plant type as independent variables. We used conventional plants as the base for the estimation and the corresponding coefficient was set to zero. Table 3 and Figure 1 present the estimation results. The estimated coefficients in the second column of Table 3 imply that, except for plants grown with organic fertilizers, participants' interests in other types of plants were all significantly different from their interest in conventional plants. Participants' interest in organic plants was significantly lower than their interest in conventional plants, whereas their interests in other types of sustainable plants were all significantly higher than their interest in conventional plants. We illustrated the value of the coefficients in Figure 1. If the confidence interval covers zero, it means participants' interest in the corresponding type of plants is not significantly different from the interest in conventional plants. The random individual effect is highly significant, which indicates that the mixed order probit model should be used instead of the standard probit model to estimate consumers' interests in different plant types.

To further explore if participants' interests in different types of sustainable plants were significantly different from each other, we conducted Wald tests for the equality of coefficients. The estimation results are in Table 4, which shows that participants' relative interest in organic plants is significantly lower than their interest in all other categories. Participants' interest in sustainable plants is lower than that in locally grown plants and plants grown in biodegradable, compostable, and recycled pots but significantly higher than their interest in plants grown with organic

Table 2. Average interest in different types of plants $(1=$ low interest, $7=$ high interest $)$ demonstrated by participants in an online survey regarding consumer attitudes and preferences for locally grown, organically grown, or sustainably grown ornamental plants.

\begin{tabular}{lcc}
\hline Variable & Mean & SE \\
\hline Conventional & 3.60 & 1.95 \\
Organic & 3.27 & 1.91 \\
Sustainable & 3.70 & 1.96 \\
Local & 4.14 & 2.09 \\
Organic fertilizer & 3.56 & 2.00 \\
Efficient greenhouse & 3.74 & 1.97 \\
Biopots & 4.15 & 2.07 \\
Compost pots & 4.06 & 2.06 \\
Recycle pots & 4.00 & 2.02 \\
\hline
\end{tabular}


Table 3. Mixed ordered probit estimation results of the interest in different types of plants (conventional plants are used as base with coefficient of zero).

\begin{tabular}{lccc}
\hline Variables & Estimated parameters & SE & Confident intervals \\
\hline Organic & $-0.326^{* * * z}$ & 0.062 & $(-0.447,-0.205)$ \\
Sustainable & $0.124^{* *}$ & 0.061 & $(0.004,0.245)$ \\
Local & $0.596^{* * *}$ & 0.061 & $(0.476,0.719)$ \\
Organic fertilizer & -0.029 & 0.061 & $(-0.149,0.092)$ \\
Efficient greenhouse & $0.155^{* *}$ & 0.061 & $(0.035,0.275)$ \\
Biopots & $0.593^{* * *}$ & 0.062 & $(0.472,0.713)$ \\
Compost pots & $0.503^{* * *}$ & 0.061 & $(0.383,0.623)$ \\
Recycle pots & $0.431^{* * *}$ & 0.061 & $(0.311,0.551)$ \\
$u_{0 \mathrm{y}}$ & $-1.202^{* * *}$ & 0.058 & \\
$u_{1}$ & $-0.596^{* * *}$ & 0.055 & \\
$u_{2}$ & $0.113^{* *}$ & 0.054 & \\
$u_{3}$ & $1.104^{* * *}$ & 0.054 & \\
$u_{4}$ & $1.885^{* * *}$ & 0.058 & \\
$u_{5}$ & $2.725^{* * *}$ & 0.064 & \\
$\gamma_{i}$ & $2.338^{* * *}$ & 0.086 & \\
${ }^{2}$ Double asterisks $(* *)$ and triple asterisks $(* * *)$ denote significance at $5 \%$ and $1 \%$ levels, respectively. \\
${ }^{\mathrm{y}} u_{0}$ to $u_{5}$ are the cutoff points in the mixed order probit model. & &
\end{tabular}

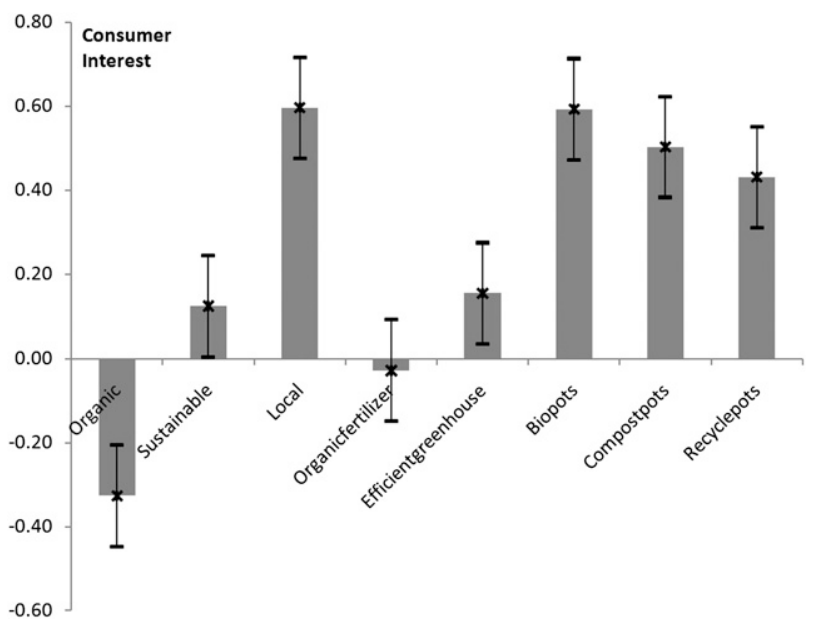

Fig. 1. Participants' interest in different types of plants, estimation results from ordered probit model (conventional plants are used as base with coefficient of zero). The horizontal axis is the plant type and the vertical axis is the relative consumers' interests in different types of plants compared with conventional plants. The higher the blue column, the higher the relative interest in the associated plant type. The black vertical lines are the confidence intervals of the relative interest level. If the confidence interval does not cover the horizontal axis, it means the interest in the particular plant type is not significantly different from that in conventional plants.

Table 4. The Wald test statistics of the equality of the coefficients of different types of plants in the mixed order probit estimation., ${ }^{z, y}$

\begin{tabular}{|c|c|c|c|c|c|c|c|c|}
\hline \multirow[b]{2}{*}{$\mathrm{b}_{2}$} & \multicolumn{8}{|c|}{$b_{1}$} \\
\hline & Organic & Sustainable & Local & $\begin{array}{l}\text { Organic } \\
\text { fertilizer }\end{array}$ & $\begin{array}{c}\text { Efficient } \\
\text { greenhouse }\end{array}$ & Biopots & $\begin{array}{l}\text { Compost } \\
\text { pots }\end{array}$ & $\begin{array}{c}\text { Recycle } \\
\text { pots }\end{array}$ \\
\hline Organic & - & & & & & & & \\
\hline Sustainable & $52.79 * * *$ & - & & & & & & \\
\hline Local & $219.05^{* * *}$ & $59.04 * * *$ & - & & & & & \\
\hline $\begin{array}{l}\text { Organic } \\
\text { fertilizer }\end{array}$ & $23.09 * * *$ & $6.15^{* *}$ & $102.73 * * *$ & - & & & & \\
\hline $\begin{array}{l}\text { Effcient } \\
\text { greenhouse }\end{array}$ & $60.31 * * *$ & 0.24 & $51.94 * * *$ & $8.88 * * *$ & - & & & \\
\hline Biopots & $216.54 * * *$ & $57.88^{* * *}$ & 0.00 & $101.09 * * *$ & $50.84 * * *$ & - & & \\
\hline Compost pots & $178.09^{* * *}$ & $38.12 * * *$ & 2.36 & $74.66^{* * *}$ & $32.4 * * *$ & 2.16 & - & \\
\hline Recycle pots & $149.2 * * *$ & $25.08 * * *$ & $7.37 * * *$ & $56.01 * * *$ & $20.47 * * *$ & $7.00^{* * * *}$ & 1.40 & - \\
\hline
\end{tabular}

${ }^{2}$ The null hypothesis is $b_{1}-b_{2}=0$; the alternative hypothesis is $b_{1}-b_{2} \neq 0$.

${ }^{y}$ Double asterisks $(* *)$ and triple asterisks $(* * *)$ denote significance at $5 \%$ and $1 \%$ levels, respectively. The critical values are 1.96 for $5 \%$ significance level and 2.58 for $1 \%$ significance level, respectively.

fertilizers. Participants' interest in local plants is significantly higher than their interest in plants grown with organic fertilizers, plants grown in efficient greenhouses, and plants grown in recyclable pots. However, partici- pants' interest in locally grown plants is not significantly different from their interest in plants grown in biodegradable and compostable pots. Participants show lower interest in plants grown in energy-efficient greenhouses than the plants grown in biodegradable, compostable, and recycled pots. Their interest in plants grown in biodegradable pots is statistically higher than their interest in plants grown in recycled pots but is not significantly different from their interest in compostable pots. Their interest in compostable pots is not significantly different from that in recycled pots.

To investigate how consumer sociodemographic variables affect their interests in different types of plants, we ran an ordered probit model for each type of plant over a set of participants' background variables (Table 5). We can see that participants' age significantly affects their interest in organic plants and compostable pots with younger consumers showing higher levels of interest. We found the older the participants, the higher the interest in compostable pots

We also found the higher the participants' education level, the lower the interest in plants grown in energy-efficient greenhouses. Participants' gender significantly affects their interests in different types of plants and we found compared with male participants, female participants were more interested in locally grown plants, plants grown with organic fertilizers, plants grown in energy-efficient greenhouses, and plants grown in biodegradable, compostable, and recyclable pots.

Participants with children younger than 12 years of age at home were more interested in organic plants. This is similar to the results from previous studies that indicate consumers who had children were more willing to buy organic food products because they were concerned about the health of their children (Yue et al., 2007). Those participants who have a detached house were more interested in plants grown in compostable pots. We found the larger the participants' household size, the lower the interest in organic plants and plants grown with organic fertilizers. This is consistent with earlier findings that people with larger household size were less interested in organic food products (Yue et al., 2010a).

We found participants who spent more of their food budget on organic food purchases were also more interested in organic, locally grown, and sustainable plants; plants grown with organic fertilizers and in energy-efficient greenhouses; and plants grown in the three types of sustainable pots. As mentioned earlier, consumers who purchase organic food products were more concerned with their own health as well as their environmental impacts. Therefore, it is expected that those consumers who were more concerned about the environment or their own health were more interested in organic plants or plants that were produced in sustainable manners. Those participants who spent more on garden-related products were more interested in all the plants in our study than those people who spent less on garden-related products.

Our estimation results also show that participants who have purchased different types of plants in the past year have different levels of interest in the various types of "sustainable" plants. For instance, participants who have purchased annuals, herbs, and vegetables 
Table 5. Ordered probit estimation results of factors affecting the interest in different types of plants.

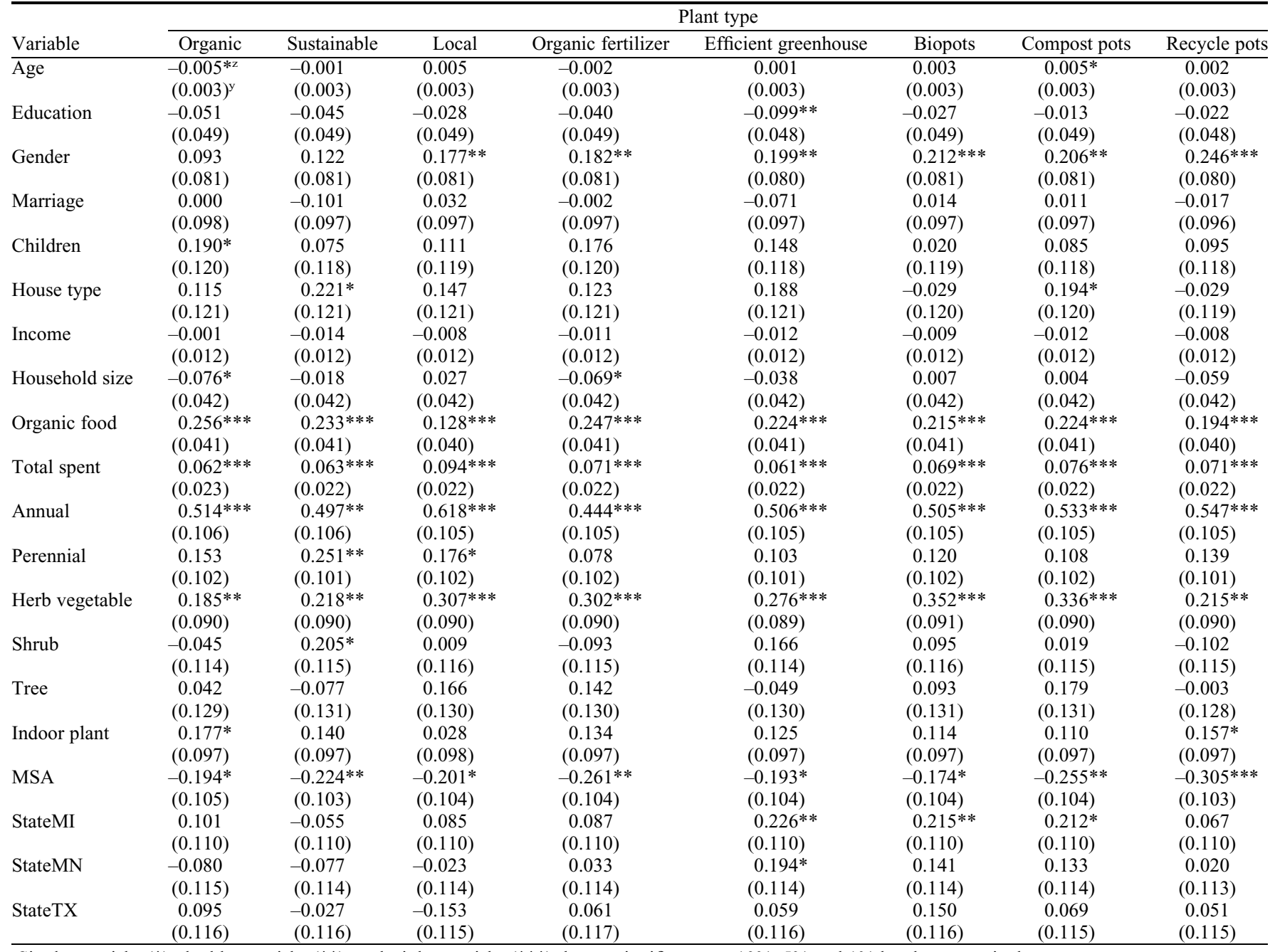

${ }^{2}$ Single asterisks $(*)$, double asterisks $(* *)$, and triple asterisks $(* * *)$ denote significance at $10 \%, 5 \%$ and $1 \%$ levels, respectively.

${ }^{y_{S E S}}$ in parentheses. The cutoff points of the ordered probit model are not reported as a result of space limit and they are available on readers' request.

in the past year have a greater interest in all of the "sustainable" plants in our study. Participants are less interested in organic plants in general, but they are more interested in buying organic plants that produce herbs and vegetables. The results are intuitive because consumers will eat the vegetables produced from these plants eventually and they perceive products produced from organic plants as healthier. Participants who purchased perennials in the past year are more interested in purchasing sustainable plants and locally grown plants than those people who have not purchased perennials. Participants who purchased shrubs in the past year are more interested in sustainable plants than those who have not purchased shrubs in the past year. Whether a participant had purchased trees in the past year did not affect their interest in the plants of our study. Interestingly, those participants who have purchased indoor plants are more interested in organic plants. The coefficients of the MSA variable for each type of plant are significant and negative, which indicates that participants who live in urban or suburban areas are less interested in all the types of plants in our study than those people who live in rural areas. We also found that there are some state-level differences among participants in terms of their interest in different types of plants. In the estimation, we used Indiana as the base for estimation, which means the coefficient of Indiana was set to zero. We found that participants from Michigan were more interested in plants grown in energy-efficient greenhouses and plants grown in biodegradable and compostable pots than participants from Indiana. We also found participants from Minnesota were more interested in plants grown in energy-efficient greenhouses than participants from Indiana.

\section{Conclusions}

Previous studies have shown consumers' interest in organic food products. Our study finds that consumers are not as enthusiastic about plants or their fertilizers being "organic." This is because the health concerns (pesticide residues, nutritional value, and food safety) associated with food products are not as big an issue for plants. However, consumers are more interested in plants being locally produced, similar to the public's ever-increasing interest in local food products. One of the main reasons consumers purchase local products is to support the local economy and local farmers. In this sense, both local food products and local plants can achieve the same objective. Therefore, we see consumers' high interest in buying locally grown plants corollary to their interest in buying local food products.

Previous studies have shown consumer demand for product stewardship or environmentally conscious products is rapidly rising. For many participants in our survey, "sustainability" means "eco- or environmentally friendly" or "energy-saving or energy-efficient or energyconserving." With the increasing emphasis on "ecofriendly" and "renewable energy" in the United States and around the world, more consumers are becoming aware of the importance of consuming products that are sustainable, which is also true for plants. Among the sustainable production practices, consumers are most concerned about the plants' pots. According to Hall et al. (2010) and Yue et al. (2010b), nearly every floral crop and many nursery crops are grown in plastic containers. Botts (2007) reported that making nursery pots, flats, and cell packs uses $\approx 320$ million pounds of plastic annually. Instead of being interested in making plants themselves more sustainable, consumers are more interested in 
making the pots more sustainable. Among the different types of pots, biodegradable and compostable pots are more desirable than recyclable pots.

The results have important marketing implications for the green industry in developing profitable niche markets. Among the sustainable practices, the nursery and floricultural industry should focus on promoting locally grown plants and plants grown in biodegradable and compostable pots. Marketing plants as "sustainable" or "grown in energy-efficient greenhouses" has the second best potential. Unlike food products, organic plants do not trigger high and prevailing interest among consumers as hypothesized by some earlier studies.

Our findings also indicate that the sociodemographic background of consumers affects their preferences for different types of plants, which also has important implications for target marketing. For example, we found that organic food purchasers were more interested in organic plants than non-organic feed purchasers, an important implication for plants produced in sustainable ways by the green industry.

The purpose of this study is to gain general insight into the interest of consumers in different types of sustainable plants and serve as a pioneer study in this research area. Bear in mind that the sample frame of this study is from four states (Minnesota, Indiana, Michigan, and Texas), so it is not necessarily representative of the entire U.S. population. Also, this study is a hypothetical survey without the exchange of money and goods, which might lead to some bias in results. In the future, non-hypothetical studies are needed to validate the results in different areas of the country.

\section{Literature Cited}

Basu, A.K., N.H. Chau, and U. Grote. 2004. On export rivalry and the greening of agriculture-The role of eco-labels. Agr. Econ. 31:135-147.
Becker, T. 2000. Consumer perception of fresh meat quality: A framework for analysis. Brit. Food J. 102:158-176.

Blend, J.R. and E.O. Van Ravenswaay. 1999. Measuring consumers' demand for ecolabeled apples. Amer. J. Agr. Econ. 81:10721077.

Botts, B. 2007. Beauty and the plastic beast. Chicago Tribune. 9 Oct. $2007<\mathrm{http}: / /$ www. chicagotribune.com/news/local/nearwest/chi0610plastic_jpjun10,1,5806552.story>.

Brown, A. 2002. Farmers' market research 1940-2000: An inventory and review. Amer. J. Altern. Agr. 17:167-176.

Brown, C. 2003. Consumers' preferences for locally produced food: A study in southeast Missouri. Amer. J. Altern. Agr. 18:213-224.

Demeritt, L. 2002. All things organic 2002: A look at the organic consumer. The Hartman Group, Bellevue, WA.

Hall, C., B.L. Campbell, B. Behe, C. Yue, R.G. Lopez, and J.H. Dennis. 2010. The appeal of biodegradable packaging to floral consumers. HortScience 45:583-591.

Hall, C., A. Hodges, and J. Haydu. 2005. Economic impact of the green industry. 9 Oct. 2008. $<$ http://hbin.tamu.edu/greenimpact.html $>$.

McCullough, D. 1998. Web-based market research: The dawning of a new age. Direct Marketing 61:36-38.

Nimon, W. and J. Beghin. 1999. Are Eco-Labels Valuable? Evidence from the Apparel Industry. Amer. J. Agr. Econ. 81:801-811.

Olson, J.C. and J. Jacoby. 1972. Cue utilization in the quality perception process. Third Annual Conference of the Association for Consumer Research, Chicago, IL. p. 167-179.

Schifferstein, H.N.J. and P.A.M. Oude Ophuis. 1998. Health-related determinants of organic food consumption in The Netherlands. Food Qual. Prefer. 9:119-133.

Stewart, A. 2007. Flower confidential: The good, the bad, and the beautiful in the business of flowers. Algonquin Books of Chapel Hill, Chapel Hill, NC.

Thompson, G.D. and J. Kidwell. 1998. Explaining the choice of organic produce: Cosmetic defects, prices, and consumer preferences. Amer. J. Agr. Econ. 80:277-287.
Tsakiridou, E., K. Mattas, and Z. Mpletsa. 2009. Consumers' food choices for specific quality food products. J. Food Prod. Mark. 15:200212.

USDA National Agricultural Statistics Service. 2010. Floriculture crops 2009 summary. 9 Oct. 2008. $<$ http://usda.mannlib.cornell.edu/MannUsda/ viewDocumentInfo.do?documentID=1072>.

Veisten, K. 2007. Willingness to pay for ecolabeled wood furniture: Choice-based conjoint analysis versus open-ended contingent valuation. J. For. Econ. 13:29-48.

Wessels, C.R., R.J. Johnson, and D. Holger. 1999. Assessing consumer preferences for ecolabeled seafood: The influence of species, certifier, and household attributes. Amer. J. Agr. Econ. 81: 1084-1089.

Willer, H., M. Yuseffi-Menzler, and N. Sorensen. 2008. The world of organic agriculture: Statistics and emerging trends 2008. International Federation of Organic Agriculture Movements (IFOAM), Germany. 2 Nov. 2009. <http://orgprints.org/ 13123/4/world-of-organic-agriculture-2008.pdf $>$

Yue, C., F. Alfnes, and H.H. Jensen. 2009. Discounting spotted apples: Investigating consumers' willingness to accept cosmetic damage in an organic product. J. Agr. Appl. Econ 14:29-46.

Yue, C. and B.K. Behe. 2008. Estimating U.S consumers' choice of floral retail outlets. HortScience 43:764-769.

Yue, C., C. Grebitus, M. Bruhn, and H.H. Jensen. 2010a. Marketing organic and conventional potatoes in Germany. J. Intl. Food Agribus. Mark. 22:164-178.

Yue, C., C. Hall, B. Behe, B. Campbell, J. Dennis, and R. Lopez. 2010b. Are consumers willing to pay more for biodegradable containers than for plastic ones? Evidence from hypothetical conjoint analysis and non-hypothetical experimental auctions. J. Agr. Appl. Econ. 42:757-772.

Yue, C., H.H. Jensen, D.S. Mueller, G.R. Nonnecke, and M.L. Gleason. 2007. Estimating consumers' valuation of organic and cosmetically damaged apples. HortScience 42:1366-1371.

Yue, C. and C. Tong. 2009. Organic or local? Investigating consumer preference for fresh produce using a choice experiment with real economic incentives. HortScience 44:366371. 